\author{
Paulina Wyszyńska-Ślufińska \\ Uniwersytet Gdański \\ paulina.wyszynska-slufinska@ug.edu.pl \\ ORCID: https://orcid.org/0000-0002-7468-3639
}

\title{
Kilka refleksji o skutkach odszkodowawczych bezprawnego wykluczenia sportowca $z$ igrzysk olimpijskich lub mistrzostw świata
}

http://dx.doi.org/10.12775.SIT.2021.043

\section{Wprowadzenie}

Jednym $z$ poważniejszych problemów w sporcie są przypadki niesłusznego wykluczenia sportowca $z$ udziału w igrzyskach olimpijskich lub mistrzostwach świata. Tytułem przykładu można wskazać sytuację polskich pływaków podczas Igrzysk Olimpijskich w Tokio w lipcu 2021 r. Zgodnie $z$ doniesieniami medialnymi sześciu pływaków zostało wykluczonych $\mathrm{z}$ udziału w igrzyskach, a jako przyczynę wykluczenia wskazywano błąd w zakresie formalnego zgłoszenia sportowców popełniony przez Polski Związek Pływacki lub błąd Międzynarodowej Federacji Pływackiej (Fédération Internationale De Natation, FINA) ${ }^{1}$. Zawodnicy zapowiadali pozwanie związku

\footnotetext{
${ }^{1}$ R. Leniarski, Sześcioro polskich olimpijczyków $w$ Tokio wykluczonych z igrzysk, https://wyborcza.pl/7,154903,27335838, szescioro-polskich-olimpijczykow-w-tokio-wykluczonych-z-igrzysk.html; Smutne obrazki na Okęciu. Polscy pływacy $w$ atmosferze skandalu wrócili z Tokio. Padły bardzo gorzkie słowa, https://sport.fakt.pl/warszawa-plywacy-wykluczeni-z-igrzysk-olimpijskich-wrocili-z-tokio/gwpmkzk (dostęp: 8.08.2021 r.).
} 
krajowego i domaganie się naprawienia wyrządzonej im szkody². Nie jest to jednak pierwszy taki przypadek dotyczący naszych krajowych zawodników. Podobny los spotkał innego pływaka, który w 2016 r. nie został zgłoszony do startu w eliminacjach w pływaniu na 100 metrów stylem dowolnym w Igrzyskach Olimpijskich w Rio. W efekcie został on pozbawiony możliwości udziału w igrzyskach ${ }^{3}$. Kwestia ewentualnej odpowiedzialności w przypadku wykluczenia z udziału w igrzyskach olimpijskich lub mistrzostwach świata wydaje się więc szczególnie aktualna, a także interesująca zarówno w aspekcie praktycznym, jak i teoretycznym.

W dalszej części artykułu uwaga zostanie poświęcona ustaleniu, czy i na jakiej podstawie organizacje sportowe mogą ponieść odpowiedzialność odszkodowawczą wobec sportowca, a następnie zostaną omówione wybrane zagadnienia problematyki szkody podlegającej naprawieniu. Należy bowiem pamiętać, że w dzisiejszych czasach sport niesie za sobą nie tylko wartości aksjologiczne, lecz ma także istotny wymiar ekonomiczny. Pozbawienie sportowca szansy udziału w zawodach na szczeblu międzynarodowym może pociągnąć za sobą, oprócz ujemnych przeżyć natury psychicznej, również istotny uszczerbek majątkowy.

\section{Bezprawność działania lub zaniechanie organizacji sportowych w kontekście odpowiedzialności odszkodowawczej}

Nie jest jasne, czym jest tzw. prawo sportowe. Zarówno w polskiej, jak i zagranicznej doktrynie prezentowane są jego różne defini$\mathrm{cje}^{4}$. Pojęcie to obejmuje m.in. reguły i regulacje przyjęte przez

${ }^{2}$ A. Gardulska, Wykluczeni z igrzysk pływacy wrócili do kraju. Planuja pozew, https://wyborcza.pl/7,154903,27341579, wykluczeni-z-igrzysk-plywacy-wrocili-do-kraju-planuja-pozew.html (dostęp: 8.08.2021 r.).

${ }^{3}$ O. Krzysztofik, Rio 2016: skandal! Konrad Czerniak nie wystartowat $z$ absurdalnego powodu, https://sportowefakty.wp.pl/rio-2016/621113/ rio-2016-skandal-konrad-czerniak-nie-wystartowal-z-absurdalnego-powodu (dostęp: 8.08.2021 r.).

${ }^{4}$ Zob. K. Vieweg, P. Staschik, The Lex Sportiva. The Phenomen and its 
państwowe (krajowe) oraz międzynarodowe organizacje sportowe, a także orzecznictwo Trybunału Arbitrażowego ds. Sportu z siedzibą w Lozannie ${ }^{5}$. Autonomia organizacji sportowych przejawia się m.in. w ich samoregulacji, co oznacza, że są one zazwyczaj uprawnione do stanowienia własnych zasad, reguł gry czy postanowień organizacyjnych $^{6}$. Należy podkreślić, że regulacje przyjmowane na szczeblu krajowym (w szczególności statuty związków sportowych) muszą być zgodne $z$ postanowieniami federacji (organizacji) międzynarodowych ${ }^{7}$. Na sytuację prawną sportowca będą mieć zatem wpływ również postanowienia tzw. regulaminów sportowych (nazywane także standardami, politykami etc. ${ }^{8}$ ) oraz postanowienia umów zawieranych przez sportowców $z$ organizacjami sportowymi ${ }^{9}$. Choć regulacje organizacji sportowych mają charakter pozanormatywny (nie wpisują się w katalog prawa powszechnie obowiązującego, o jakim mowa w art. 87 polskiej Konstytucji ${ }^{10}$ ), to są one wiążące dla podmiotów uczestniczących w sporcie zorganizowanym $^{11}$. W konsekwencji organizacje sportowe mają monopolistycz-

Meaning in the International Sporting Arena, w: Lex Sportiva, ed. K. Vieweg, Berlin 2015, s. 21.

${ }^{5}$ C.R. Siekmann, What is Sports law? A reassessment of Content and Terminology, w: Lex Sportiva: What is Sports Law?, eds. C.R. Siekmann, J. Soek, The Hague 2012, s. 359. Por. M. Leciak (red.), M. Biliński, K. Grabska-Luberadzka, R. Piechota, H. Radtke, B. Rischka-Słowik, K. Tetłak, Prawo sportowe, Warszawa 2018, s. 35 i n.; T. Widłak, Wybrane uwagi na temat charakteru $i$ statusu lex sportiva $w$ przestrzeni prawnomiędzynarodowej, „Ruch Prawniczy, Ekonomiczny i Socjologiczny” 2015, nr 4, s. 81-92.

${ }^{6}$ K. Romaniec, Zjawisko niekompatybilności pozaprawnych regulacji sportowych, w: Kompatybilność pozaprawnych regulacji sportowych z regulacjami prawnymi, red. A.J. Szwarc, Poznań 2014, s. 72.

7 Ibidem, s. 71-72.

8 J. Jabłońska-Bonca, Istota spójności regulacji prawnych oraz niesprzeczności regulacji pozaprawnych z regulacjami prawnymi, w: Kompatybilność pozaprawnych regulacji sportowych $z$ regulacjami prawnymi, red. A.J. Szwarc, Poznań 2014, s. 61.

${ }^{9}$ H. Goik, Specyfika porzadku sportowego - wprowadzenie do problematyki umów o uprawianie sportu, w: Europeizacja prawa prywatnego, red. M. Pazdan, W. Popiołek, E. Rott-Pietrzyk, M. Szpunar, Warszawa 2008, s. 315-338.

10 Konstytucja Rzeczypospolitej Polskiej z dnia 2 kwietnia 1997 r., Dz.U. Nr 78, poz. 483 ze zm.

11 K. Foster, Is there a Global Sports Law?, w: Lex Sportiva: What is Sports 
ną pozycję wobec sportowca i istotny wpływ na kształtowanie jego sytuacji prawnej.

Przejawem szerokiej autonomii organizacji sportowych w Polsce jest przyznanie w Ustawie $z$ dnia 25 czerwca 2010 r. o sporcie ${ }^{12}$ (dalej: ustawa o sporcie) szeregu uprawnień polskim związkom sportowym, które uzyskują osobowość prawną z chwilą wpisu do Krajowego Rejestru Sądowego ${ }^{13}$. Jako wyłączną kompetencję związków sportowych polski legislator wskazał m.in. powoływanie do kadry narodowej, a także przygotowanie do igrzysk olimpijskich, paraolimpijskich, mistrzostw świata czy Europy ${ }^{14} . Z$ kolei zgodnie z treścią przepisów wykonawczych do art. 27 i 28 Karty Olimpijskiej $^{15}$ (stanowiącej fundamentalne zasady olimpizmu ${ }^{16}$ ) decyzje o zgłoszeniu zawodnika na igrzyska olimpijskie podejmują narodowe komitety olimpijskie (w naszym krajowym porządku jest to Polski Komitet Olimpijski, dalej: PKOl), opierając się na propozycjach zawodników przedstawionych przez uprawnione federacje krajowe. PKOl jest związkiem stowarzyszeń oraz samodzielną organizacją pozarządową (art. 24 ustawy o sporcie) ${ }^{17}$. W kontekście tytułowej problematyki należy się zastanowić, czy w przypadku naruszenia własnych regulacji organizacyjnych przez organizacje sportowe ich działanie lub zaniechanie można zakwalifikować jako bezprawne $\mathrm{w}$ świetle prawa cywilnego. Ustalenie bezprawności rozumianej jako sprzeczność z przepisami prawa powszechnie obowiązującego oraz zasadami współżycia społecznego ${ }^{18}$ jest bowiem punktem

Law?, eds. R.C. Siekmann, J. Soek, The Hague 2012, s. 39.

12 Tekst jednolity: Dz.U. z 2020 r. poz. 1133.

13 Zob. przepis art. 12 ust. 2 ustawy o sporcie.

14 Zob. przepis art. 13 ust. 1 pkt 3 ustawy o sporcie.

15 https://olimpijski.pl/wp-content/uploads/2020/09/Karta_Olimpijska. pdf (dostęp: 8.08.2021 r.).

16 S. Fundowicz, Prawo sportowe, Warszawa 2013, s. 128 i n.

17 Odnośnie do charakteru prawnego Pkol zob. E.J. Krześniak, w: Ustawa o sporcie. Komentarz, Warszawa 2020, Lex, art. 24.

18 E. Bagińska, w: System prawa administracyjnego, t. 12: Odpowiedzialność odszkodowawcza $w$ administracji, red. E. Bagińska, J. Parchomiuk, Warszawa 2016, s. 335; eadem, Odpowiedzialność odszkodowawcza za wykonywanie władzy publicznej, Warszawa 2006, s. 315-316; S. Grzybowski, System prawa prywatnego, t. 1, Wrocław 1974, s. 206 i n. 
wyjścia do rozważań o odpowiedzialności cywilnej. Ze względu na brak przykładów rozstrzygnięć w polskim orzecznictwie w zakresie ustalenia bezprawności w interesujących nas przypadkach warto odnieść się do praktyki judykatury zagranicznej.

Jako pierwszy przykład można wskazać orzeczenie w sprawie o sygn. Pfv III 21.257/2016 BH 2016 no 333 wydane przez Sąd Najwyższy Węgier ${ }^{19}$. W sprawie powód domagał się naprawienia szkody w postaci utraty nagrody w igrzyskach olimpijskich i zwrotu kosztów poniesionych w celu przygotowania się do igrzysk. Sąd rozważał, czy wykluczenie sportowca przez Węgierski Komitet Olimpijski $z$ udziału $\mathrm{w}$ igrzyskach było bezprawne. W celu ustalenia obiektywnego kryterium bezprawności sąd odniósł się nie tylko do norm prawnych zawartych w krajowych przepisach ustawy o sporcie, lecz także do treści Karty Olimpijskiej. Skład orzekający uznał, że $z$ uwagi na stwierdzenie stosowania przez sportowca dopingu krajowy komitet był uprawniony do podjęcia decyzji o wyłączeniu zawodnika $z$ udziału w igrzyskach. Jego działaniu nie można było zatem przypisać niezgodności z prawem, a w konsekwencji podstawa prawna roszczeń powoda upadła. Argumentacja sądu węgierskiego powinna zostać podzielona także w świetle prawa polskiego w zakresie, w jakim przy ocenie elementu bezprawności działania lub zaniechania organizacji sportowej uwzględniono również treść postanowień o charakterze pozanormatywnym.

Problematyka odpowiedzialności krajowej federacji sportowej była rozpatrywana także przez Tribunal Federal Suisse w orzeczeniu z dnia 10 października 1995 r., sygn. ATF 121 III $350^{20}$. Sprawa dotyczyła uniemożliwienia udziału w mistrzostwach świata w wrestlingu. Stan faktyczny kształtował się następująco. Szwajcarska Federacja Wrestlerów Amatorów przedstawiła oficjalne kryteria, jakie powinien spełniać sportowiec w celu reprezentowa-

19 Wyrok Kuria Pfv III 21.257/2016 BH 2016 no 333, z komentarzem A. Menyhard, Hungary, w: European Tort Law 2016, eds. E. Karner, B.C. Steiniger, Berlin-Boston 2017, s. 273.

20 Orzeczenia z dnia 10 października 1995 r., sygn. ATF 121 III 350, z komentarzem B. Winiger, A. Campi, C. Duret, J. Retamozo, w: Digest of European Tort Law, Vol. 3: Essential Cases on Misconduct, eds. B. Winiger, E. Karner, K. Oliphant, Berlin-Boston 2018, s. 492-494. 
nia kraju podczas mistrzostw świata w 1989 r. Mimo spełnienia wszystkich wymagań przez powoda Federacja ustanowiła nowy warunek dopuszczenia do udziału w mistrzostwach, tj. wygranie dodatkowej walki. Powód walkę przegrał i $z$ tego względu nie został dopuszczony do rozgrywek na szczeblu międzynarodowym. Zawodnik pozwał Federację, domagając się zapłaty odszkodowania w wysokości 10 tys. franków szwajcarskich tytułem zwrotu kosztów poniesionych $\mathrm{w}$ związku $\mathrm{z}$ przygotowaniem się do kwalifikacji w mistrzostwach, a także zadośćuczynienia za doznaną krzywdę. Trybunał zakwalifikował działanie organizacji jako bezprawne $z$ uwagi na sprzeczność $z$ zasadami dobrej wiary - sportowiec nie mógł przecież przewidzieć, że Federacja ustali dalsze kryteria warunkujące udział zawodnika w rozgrywkach. $Z$ tych przyczyn sąd orzekł o odpowiedzialności organizacji na zasadzie winy, przewidzianej w art. 41 szwajcarskiego kodeksu cywilnego. Podkreślono, że federacja miała pozycję monopolistyczną, a między stronami nie istniała więź kontraktowa. Sąd odwołał się do niemieckiej koncepcji Vertrauenschaftung, polegającej na naruszeniu zaufania w relacji między stronami. W ocenie składu orzekającego ustanowienie dodatkowego kryterium stanowiło naruszenie uprzednio występującego zaufania powoda do Federacji ${ }^{21}$.

Przenosząc rozważania na grunt prawa polskiego, można uznać, że w sytuacji, gdy występują jasno określone kryteria, które dany sportowiec spełnia, fakt nieuzasadnionego wykluczenia $z$ udziału w danych mistrzostwach należałoby zakwalifikować jako nadużycie przez organizację sportową pozycji monopolistycznej względem sportowca oraz jako naruszenie relacji zaufania występującej między tymi podmiotami. W konsekwencji takie postępowanie jest sprzeczne $z$ zasadami współżycia społecznego i bezprawne ${ }^{22}$. Zasady nadużycia pozycji monopolistycznej oraz relacji zaufania między kontrahentami zostały sformułowane w orzecznictwie i doktrynie

${ }^{21}$ Rozstrzygnięcie sądu spotkało się z dużą krytyką doktryny. Zob. B. Winiger, A. Campi, C. Duret, J. Retamozo, op.cit., s. 493-494.

${ }^{22}$ Por. M. Wilejczyk, Zagadnienia etyczne części ogólnej prawa cywilnego, Warszawa 2014, s. 99 i n.; Z. Radwański (red.), System prawa prywatnego. Prawo cywilne - część ogólna, t. 2, Warszawa 2008, s. 237 i n. 
w kontekście wolności kontraktowej, jednakże, w mojej ocenie, znajdą także zastosowanie w relacji sportowiec - organizacja sportowa. Niesłuszne wykluczenie $\mathrm{z}$ udziału w danych rozgrywkach sportowych będzie zatem stanowić czyn niedozwolony i uzasadniać odpowiedzialność ex delicto ${ }^{23}$. Problematyczne jednak może się okazać ustalenie właściwej podstawy prawnej odpowiedzialności deliktowej, o czym będzie mowa poniżej.

\section{Wykonywanie uprawnień przez organizacje sportowe - sfera imperium w rozumieniu przepisów o odpowiedzialności za wykonywanie władzy publicznej?}

W przywołanym już orzeczeniu szwajcarskiego sądu z dnia 10 października 1995 r. uznano odpowiedzialność federacji sportowej na podstawie ogólnej klauzuli odpowiedzialności. W prawie polskim dochodzenie roszczeń odszkodowawczych na zasadach ogólnych (art. 415 i 416 k.c.) w reżimie ex delicto implikowałoby konieczność udowodnienia winy danej organizacji sportowej ${ }^{24}$. $Z$ tego względu, mimo dominacji zasady winy w naszym krajowym systemie prawnym, warto rozważyć reżim surowej odpowiedzialności cywilnej na podstawie przepisów o wykonywaniu władzy publicznej. Ulokowanie odpowiedzialności $w$ tym reżimie jest $z$ pewnością korzystniejsze dla poszkodowanego, ponieważ przesłanką odpowiedzialności jest szeroko rozumiana bezprawność ${ }^{25}$, odpada zatem obowiązek udowodnienia winy podmiotu zobowiązanego do naprawienia szkody. Zastanówmy się zatem, czy niesłuszne wykluczenie sportowca

23 Odmiennie A. Górski, w: Odpowiedzialność odszkodowawcza polskich związków sportowych w przypadku błędów popełnionych przy powoływaniu kadry narodowej, „Przegląd Sądowy” 2016, nr 11, według którego w przypadku „błędów” w zakresie powoływania do kadry narodowej zastosowanie znajdą przepisy o odpowiedzialności w reżimie ex contractu.

${ }^{24}$ Zgodnie $z$ rozkładem ciężaru dowodowego przewidzianego $\mathrm{w}$ art. 6 Ustawy z dnia 23 kwietnia 1964 r. - Kodeks cywilny, tekst jednolity: Dz.U. z 2020 r. poz. 1740 ze zm. (dalej: k.c.).

25 E. Bagińska, w: System prawa administracyjnego, s. 210. 
z udziału w mistrzostwach świata może zostać zakwalifikowane jako wykonywanie władzy publicznej w rozumieniu imperium i tym samym uzasadniać odpowiedzialność za szkodę na zasadzie ryzyka na podstawie przepisów art. 417 i n. Kodeksu cywilnego.

Zakres podmiotowy wyznaczony normą prawną wynikającą z przepisu art. 417 § 1 k.c. został zawężony do Skarbu Państwa, jednostek samorządu terytorialnego lub innych osób prawnych wykonujących władzę publiczną z mocy prawa ${ }^{26}$. Uznaje się, że imperium przejawia się we władczej możliwości kształtowania praw i obowiązków jednostki ${ }^{27}$ na podstawie upoważnienia normatywnego ustawodawcy ${ }^{28}$, co wywołuje skutek bezpośredni wobec adresata działania lub zaniechania ${ }^{29}$. Trybunał Konstytucyjny w wyroku z dnia 19 października 2010 r., sygn. P 10/10 ${ }^{30}$, podkreślił, że związki sportowe nie są organami władzy publicznej, ale mają jednocześnie silną pozycję wobec innych podmiotów, co może przypominać relację między obywatelem a organem administracji. Powyższe stanowisko dotyczące braku przymiotu organu władzy publicznej nie wyklucza a priori przyjęcia, że związki sportowe nie mogą zostać uznane za podmioty wykonujące władzę publiczną w rozumieniu art. 417 k.c. Decydujące jest bowiem ustalenie, czy mogą one władczo oddziaływać na sytuację prawną jednostki w granicach przepisów prawa powszechnie obowiązującego ${ }^{31}$. Po pierwsze, należy wskazać, że są to jedyne osoby prawne uprawnione do powoływania do kadry narodowej. Można zatem stwierdzić, że na mocy art. 13 ustawy o sporcie doszło do delegowania na te organizacje uprawnień o charakterze władczym. Po drugie, bezprawne pozbawienie możliwości udziału w określonych mistrzostwach kreuje sytuację prawną sportowca w sposób jednostronny. Tym samym

${ }^{26}$ Ibidem, s. 283.

27 Ibidem, s. 282.

28 Ibidem, s. 284.

29 E. Bagińska, Odpowiedzialność odszkodowawcza za wykonywanie władzy publicznej, Warszawa 2006, s. 244.

30 Wyrok TK z dnia 19 października 2010 r., P 10/10, „Orzecznictwo Trybunału Konstytucyjnego - Seria A” 2010, nr 8, poz. 78.

31 Por. E. Bagińska, w: System prawa administracyjnego, s. 281 i n. 
uprawniony jest wniosek, że w tym zakresie organizacje sportowe wykonują funkcje władcze o charakterze administracyjnym (co jest domeną podmiotów prawa publicznego ${ }^{32}$ ) mimo swojego prywatnoprawnego bytu ${ }^{33}$. W konsekwencji jako podstawę prawną odpowiedzialności należy wskazać przepisy o odpowiedzialności za szkodę wyrządzoną niezgodnym z prawem działaniem lub zaniechaniem przy wykonywaniu władzy publicznej. Powyższe uwagi w zakresie rozumienia imperium należy także odnieść do sytuacji bezprawnego wykluczenia $z$ igrzysk olimpijskich.

\section{Problematyka szkody podlegającej naprawieniu}

Po dokonaniu ustaleń w przedmiocie podstaw odpowiedzialności odszkodowawczej naturalną konsekwencją jest przejście do rozważań dotyczących zakresu naprawienia szkody. W prawie polskim zakres naprawienia szkody zawsze wyznacza adekwatny związek przyczynowy $^{34}$, kompensacji zaś podlega zarówno szkoda majątkowa (obejmująca lucrum cessans oraz damnum emergens), jak i niemajątkowa ${ }^{35}$. Podstawowym sposobem indemnizacji szkody majątkowej jest zapłata odszkodowania, a na wypadek szkody niemajątkowej w postaci krzywdy - zadośćuczynienie ${ }^{36}$. W przytoczonych powyżej sprawach zagranicznych sportowcy domagali się naprawienia szkody majątkowej w postaci kosztów poniesionych tytułem przygotowywania się do kwalifikacji sportowych jako

32 Por. ibidem, s. 292.

33 Zob. argumentację hiszpańskiego Sądu Najwyższego w orzeczeniu z dnia 25 kwietnia 2017 r., sygn. 708/2017, gdzie wskazano, że ustawodawca delegował na organizacje sportowe uprawnienia w zakresie wykonywania władzy publicznej.

${ }^{34}$ T. Wiśniewski, Art. 361, w: Kodeks cywilny. Komentarz. Zobowiązania, t. 3, cz. 1, red. J. Gudowski, Warszawa 2013, s. 88.

35 M. Kaliński, w: System prawa prywatnego, t. 6: Prawo zobowiąań część ogólna, red. A. Olejniczak, Warszawa 2018, s. 93.

36 Ibidem, s. 96. 
wydatków pozostających w związku przyczynowym ze zdarzeniem szkodzącym. Nie jest wykluczone, że w razie wykazania bezprawnego wyłączenia $z$ udziału $w$ igrzyskach olimpijskich lub mistrzostwach świata szkodą podlegającą naprawieniu będą np. utracone dochody z kontraktów sponsorskich lub reklamowych. Przy czym w tych przypadkach największy problem sprowadza się do udowodnienia faktu szkody (jako przesłanki odpowiedzialności) w sposób graniczący niemalże $z$ pewnością.

Szerokie omówienie problematyki zakresu szkody wymagałoby odrębnego opracowania, dlatego poniżej skupię się na zagadnieniu utraconej szansy na udział w zawodach, przywołując przykład rozważany przez Alicję Sieczych-Drzewiecką ${ }^{37}$. Analizuje ona przypadek pływaka wykluczonego $\mathrm{z}$ udziału w igrzyskach olimpijskich w 2016 r. Autorka kwalifikuje utratę szansy na udział w zawodach olimpijskich jako naruszenie dobra osobistego i przewiduje możliwość zasądzenia zadośćuczynienia za doznaną przez sportowca krzywdę. Mimo argumentów natury aksjologicznej pogląd prezentowany przez Alicję Sieczych-Drzewiecką budzi wątpliwości. Po pierwsze, zadośćuczynienie w polskim systemie prawnym może zostać przyznane wyłącznie w przypadkach przewidzianych expressis verbis w ustawie. Otwartość katalogu dóbr osobistych w art. 23 k.c. wymaga zawsze oceny naruszonego interesu jednostki ad casum i jego kwalifikacji jako dobra osobistego ${ }^{38}$. W mojej ocenie w obowiązującym stanie prawnym brakuje uzasadnienia dla kwalifikacji szansy udziału w igrzyskach jako dobra osobistego, co wyklucza jednocześnie możliwość zasądzenia zadośćuczynienia na podstawie art. $24 \mathrm{i} \mathrm{w} \mathrm{zw.} \mathrm{z}$ art. 448 k.c. W polskiej judykaturze widoczna jest tendencja do wykorzystywania mechanizmów służących do ochrony dóbr osobistych w przypadkach, gdy sądy dostrzegają poczucie krzywdy danej jednostki i potrzebę jej kompensaty. $Z$ tego względu sądy często „kreują” dobro osobiste, by na podstawie przepisów

37 A. Sieczych-Drzewiecka, Szkoda ewentualna i utrata szansy, Warszawa 2020, s. 166.

38 T. Grzeszak, Dobro osobiste jako dobro zindywidualizowane, w: Experientia docet. Księga jubileuszowa ofiarowana Pani Profesor Elżbiecie Traple, red. T. Targosz, P. Podrecki, P. Kostański, Warszawa 2017, s. 886. 
art. 24 i 448 k.c. przyznać stosowne zadośćuczynienie ${ }^{39}$. Do takiej praktyki należy się odnieść krytycznie.

Odrzucenie koncepcji kwalifikacji utraty szansy na udział w igrzyskach olimpijskich jako dobra osobistego może uzasadniać zastosowanie teorii utraty szansy (loss of chance). Utratę szansy charakteryzuje fakt utraty nie samego rezultatu, lecz szansy na jego osiągnięcie ${ }^{40}$, co powoduje pewny i konkretny uszczerbek ${ }^{41}$. Szkoda w postaci utraconej szansy nie wpisuje się w tradycyjny model pojęcia szkody. W polskiej doktrynie brak jednolitego poglądu na temat charakteru tego rodzaju uszczerbku. Adam Szpunar kwalifikuje loss of chance jako rodzaj szkody ewentualnej ${ }^{42}$, a Ewa Bagińska jako szkodę rzeczywistą (a nie jedynie potencjalną) ${ }^{43}$. Nie jest także jasne, czy szkodę w postaci utraty szansy na uzyskanie danego rezultatu należy wpisywać w kategorię szkody majątkowej, czy stanowi ona jednak okoliczność wpływającą na zakres szkody niemajątkowej. Zdaje się, że ta ostatnia koncepcja $\mathrm{w}$ polskiej judykaturze (niestety) przeważa ${ }^{44} \mathrm{z}$ powodu przyjęcia stanowiska doktrynalnego, zgodnie $z$ którym za szkodę uznaje się skutek naruszenia dobra lub interesu prawnie chronionego ${ }^{45}$. Podzielam odmienne stanowisko prezentowane przez Adama

39 Zob. np. wyrok SO w Krakowie z dnia 7 września 2017 r., II Ca 1111/17, Lex nr 2460249, w którym przyznano zadośćuczynienie za śmierć psa rodzinnego.

40 Zob. E. Bagińska, Odpowiedzialność deliktowa $w$ razie niepewności związku przyczynowego, Toruń 2013, s. 230.

41 E. Bagińska, O granicach kompensacji szkody niemajątkowej $w$ przyszłym kodeksie cywilnym (uwagi na tle prac Komisji Kodyfikacyjnej Prawa Cywilnego), „Państwo i Prawo” 2021, nr 3, s 128.

42 A. Szpunar, Odpowiedzialność za szkodę majątkowa - szkoda na mieniu i na osobie, Bydgoszcz 1998, s. 46-47.

43 Zob. E. Bagińska, Odpowiedzialność deliktowa, s. 290 i n.

44 Zob. ibidem, s. 239 i n. wraz z przywołanym tam orzecznictwem. Pogląd dotyczący kwalifikacji utraty szansy wyłącznie jako szkody niemajątkowej prezentowany jest przez A. Sieczych-Drzewiecką w monografii pt. Szkoda ewentualna i utrata szansy, Warszawa 2020, s. 174, 182 i n.

${ }^{45}$ Za taką koncepcją szkody opowiadają się Z. Radwański, J. Panowicz-Lipska i M. Kaliński. Szerzej zob. A. Szpunar, op.cit., s. 30; i M. Kaliński, op.cit., s. 82. 
Szpunara, uznającego za szkodę samo naruszenie dóbr i interesów prawnie chronionych, a nie jego skutki ${ }^{46}$. W takiej sytuacji za Ewą Bagińską należy stwierdzić, że utracona szansa może zostać zakwalifikowana jako rzeczywista szkoda majątkowa, która ma wymiar ekonomiczny, a nie tylko jako okoliczność wpływająca na zakres szkody niemajątkowej ${ }^{47}$. Pogląd, że utrata szansy zawsze stanowi okoliczność wpływającą na zakres szkody niemajątkowej, uniemożliwia w pewnych sytuacjach naprawienie doznanej szkody (w szczególności, gdy towarzyszy temu brak naruszenia dobra osobistego jak w przypadku wykluczenia zawodnika $\mathrm{z}$ udziału w mistrzostwach świata).

$Z$ uwagi na spekulacyjny charakter sportu i związany $z$ tym

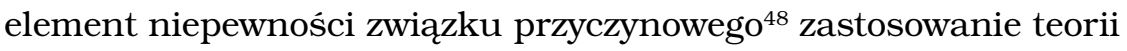
utraconej szansy w sprawach szkód wyrządzonych sportowcom może okazać się szczególnie przydatne. Niewykluczone, że polskie sądy oddaliłyby roszczenia powodów w zakresie szkody ze względu na odrzucenie koncepcji utraty szansy jako szkody majątkowej. Należy jednak podkreślić, że w sytuacji, gdy szansa na udział w zawodach była realna i występuje duży stopień prawdopodobieństwa jej zrealizowania się, szkoda majątkowa powinna podlegać kompensacji. De lege ferenda za Ewą Bagińską należy postulować rozważenie wprowadzenia do Kodeksu cywilnego dopuszczalności indemnizacji utraty szansy na osiągnięcie konkretnego rezultatu ${ }^{49}$, tak by wykluczyć wątpliwości co do dopuszczalności kompensacji tego rodzaju uszczerbku.

${ }^{46}$ A. Szpunar, op.cit., s. 30.

47 E. Bagińska, O granicach kompensacji szkody niemajątkowej, s. 128.

48 Tak podkreślono m.in. w sprawie Youst $v$. Longo (1987) 43 Cal.3d 64, 729 P.2d 728; 233 Cal. Rptr. 294.

49 E. Bagińska, Odpowiedzialność deliktowa, s. 367. 


\section{Podsumowanie}

W przypadku bezprawnego wykluczenia $\mathrm{z}$ udziału w mistrzostwach świata lub igrzyskach olimpijskich usprawiedliwione będzie roszczenie odszkodowawcze sportowca za szkodę wyrządzoną wykonywaniem władzy publicznej przez organizacje sportowe. Uprawnienie w tym zakresie zostało delegowane na organizacje sportowe przez polskiego ustawodawcę na mocy ustawy o sporcie. Realizacja tej kompetencji silnie wpływa na sferę prawną sportowca. Ulokowanie podstaw odpowiedzialności w surowym reżimie odpowiedzialności za szkodę wyrządzoną bezprawnym wykonywaniem władzy publicznej z pewnością jest korzystniejsze dla poszkodowanego, który zostanie zwolniony $z$ obowiązku udowodnienia winy. Problematyczne jednak pozostaje ustalenie zakresu szkody podlegającej naprawieniu, w szczególności w postaci utraconej szansy na udział w zawodach, $z$ tego względu należy uznać, że tradycyjne koncepcje naprawienia szkody zawodzą.

\section{STRESZCZENIE}

Kilka refleksji o skutkach odszkodowawczych bezprawnego wykluczenia sportowca $z$ igrzysk olimpijskich lub mistrzostw świata

W artykule autorka omawia wybrane aspekty problematyki odpowiedzialności cywilnej w sytuacji niesłusznego wykluczenia zawodnika sportowego $\mathrm{z}$ udziału w mistrzostwach świata lub igrzyskach olimpijskich. Analizuje ona, czy przypadek wykluczenia zawodnika $z$ danego wydarzenia sportowego można zakwalifikować jako wykonywanie władzy publicznej, a także jaki jest zakres szkody podlegającej naprawieniu. W opinii autorki nadanie określonych uprawnień organizacjom sportowym może, w określonych przypadkach, być zakwalifikowane jako wykonywanie imperium i uzasadniać odpowiedzialność cywilną na podstawie przepisów o odpowiedzialności za szkodę wyrządzoną wykonywaniem władzy publicznej.

Słowa kluczowe: wykluczenie $\mathrm{z}$ udziału w zawodach sportowych; mistrzostwa świata; igrzyska olimpijskie; władza publiczna; sport; prawo sportowe; odpowiedzialność cywilna; szkoda; utrata szansy 
484 | Paulina Wyszyńska-Ślufińska

\section{SUMMARY}

Some reflections on the civil liability consequences of the wrongful exclusion of an athlete from the Olympic Games or the world championships

The author discusses the issue of civil liability in the case of a wrongful exclusion of an athlete from a world championship or the Olympic Games. She analyses whether a case of a player's exclusion from a given sporting event can be qualified as the exercise of public authority, and what is the scope of damages subject to compensation. In her opinion, the fact of conferring certain competences on sports organizations may, in certain cases, be qualified as the exercise of public authority and justify a strict civil liability under the provisions on the exercise of public authority.

Keywords: exclusion from participation in sporting competitions; world championships; Olympic Games; public authority; sport; sports law; civil liability; damage; loss of chance

\section{BIBLIOGRAFIA}

Bagińska E., O granicach kompensacji szkody niemajątkowej $w$ przyszłym kodeksie cywilnym (uwagi na tle prac Komisji Kodyfikacyjnej Prawa Cywilnego), „Państwo i Prawo” 2021, nr 3.

Bagińska E., Odpowiedzialność deliktowa $w$ razie niepewności związku przyczynowego, Toruń 2013.

Bagińska E., Odpowiedzialność odszkodowawcza za wykonywanie władzy publicznej, Warszawa 2006.

Bagińska E., w: System prawa administracyjnego, t. 12: Odpowiedzialność odszkodowawcza $w$ administracji, red. E. Bagińska, J. Parchomiuk, Warszawa 2016.

Biliński M., Jaś-Nowopolska M., Zienkiewicz-Będźmirowska O., Arbitraż sportowy, Warszawa 2019.

Foster K., Is there a Global Sports Law?, w: Lex Sportiva: What is Sports Law?, eds. R.C. Siekmann, J. Soek, The Hague 2012.

Fundowicz S., Prawo sportowe, Warszawa 2013.

Goik H., Specyfika porządku sportowego - wprowadzenie do problematyki umów o uprawianie sportu, w: Europeizacja prawa prywatnego, red. M. Pazdan, W. Popiołek, E. Rott-Pietrzyk, M. Szpunar, Warszawa 2008. 
Górski A., w: Odpowiedzialność odszkodowawcza polskich związków sportowych $w$ przypadku błędów popełnionych przy powoływaniu kadry narodowej, „Przegląd Sądowy” 2016, nr 11.

Grzeszak T., Dobro osobiste jako dobro zindywidualizowane, w: Experientia docet. Księga jubileuszowa ofiarowana Pani Profesor Elżbiecie Traple, red. T. Targosz, P. Podrecki, P. Kostański, Warszawa 2017.

Grzybowski S., w: System prawa prywatnego, t. 1, Wrocław 1974.

Jabłońska-Bonca J., Istota spójności regulacji prawnych oraz niesprzeczności regulacji pozaprawnych $\mathrm{z}$ regulacjami prawnymi, w: Kompatybilność pozaprawnych regulacji sportowych $z$ regulacjami prawnymi, red. A.J. Szwarc, Poznań 2014.

Kaliński M., w: System prawa prywatnego, t. 6: Prawo zobowiązań - część ogólna, red. A. Olejniczak, Warszawa 2018.

Krześniak E.J., w: Ustawa o sporcie. Komentarz, Warszawa 2020.

Leciak M. (red.), Biliński M., Grabska-Luberadzka K., Piechota R., Radtke H., Rischka-Słowik B., Tetłak K., Prawo sportowe, Warszawa 2018.

McArdle D., Dispute Resolution in Sport. Atheletes, law and arbitration, London-New York 2015.

Menyhard A., Hungary, w: European Tort Law 2016, eds. E. Karner, B.C. Steiniger, Berlin-Boston 2017.

Radwański Z. (red.), System prawa prywatnego. Prawo cywilne - część ogólna, t. 2, Warszawa 2008.

Romaniec K., Zjawisko niekompatybilności pozaprawnych regulacji sportowych, w: Kompatybilność pozaprawnych regulacji sportowych z regulacjami prawnymi, red. A.J. Szwarc, Poznań 2014.

Sieczych-Drzewiecka A., Szkoda ewentualna i utrata szansy, Warszawa 2020.

Siekmann C.R., What is Sports law? A reassessment of Content and Terminology, w: Lex Sportiva: What is Sports Law, eds. C.R. Siekmann, J. Soek, The Hague 2012.

Szpunar A., Odpowiedzialność za szkodę majątkowa - szkoda na mieniu i na osobie, Bydgoszcz 1998.

Vieweg K., Staschik P., The Lex Sportiva. The Phenomen and its Meaning in the International Sporting Arena, w: Lex Sportiva, ed. K. Vieweg, Duncker \& Humblot, Berlin 2015.

Widłak T., Wybrane uwagi na temat charakteru i statusu lex sportiva $w$ przestrzeni prawnomiędzynarodowej, „Ruch Prawniczy, Ekonomiczny i Socjologiczny" 2015, nr 4. 
486 | Paulina Wyszyńska-Ślufińska

Winiger B., Campi A., Duret C., Retamozo J., w: Digest of European Tort Law, Vol. 3: Essential Cases on Misconduct, eds. B. Winiger, E. Karner, K. Oliphant, Berlin-Boston 2018.

Wiśniewski T., Art. 361, w: Kodeks cywilny. Komentarz. Zobowiązania, t. 3, cz. 1, red. J. Gudowski, Warszawa 2013. 